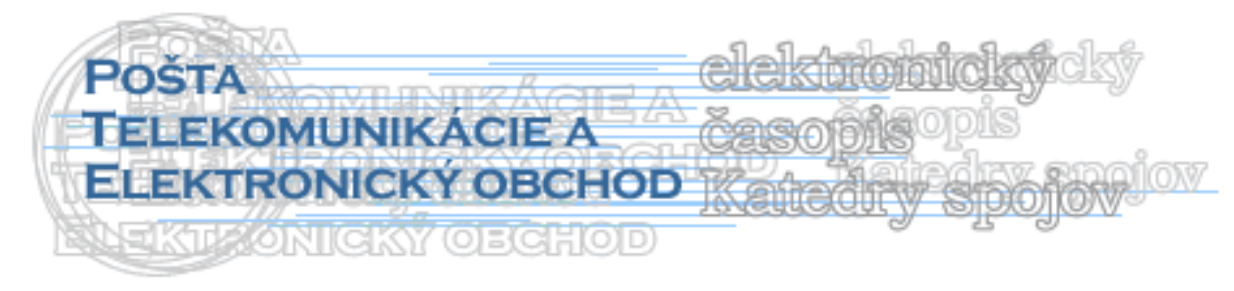

\title{
POŠTOVÁ VÝHRADA A LIBERALIZÁCIA NA EURÓPSKOM POŠTOVOM TRHU
}

\author{
Mária Rostášová* Miroslav Bát'ka ${ }^{+}$
}

\section{Na úvod}

Uplatňovanie poštovej výhrady ${ }^{1}$ ) na trhu poštových služieb, vyvoláva v poslednom období rôznorodé otázky, ktoré priamo súvisia s povinnost'ou niektorých poštových operátorov poskytovat' univerzálnu poštovú službu (UPS) na liberalizovanom poštovom trhu. V dôsledku vstupu SR do EÚ nám vyplynuli povinnosti prebrat' a zapracovávat' jednotlivé odporúčania európskych inštitúcií do našich právnych ustanovení, ktoré sa týkajú aj liberalizácie poštového trhu. Preto v súlade so smernicou 97/67/EC a so smernicou 2002/39/EC boli v Zákone o poštových službách č. 507/2001 Z.z. a novelizácii tohto zákona č. 15/2004 Z.z. zapracované jednotlivé právne ustanovenia $z$ európskych smerníc. V týchto zákonoch je definovaná aj poštová výhrada a univerzálna poštová služba v súlade s európskou legislatívou.

\section{Definičné vyjadrenie}

Poskytovatel'om univerzálnej služby v Slovenskej republike je Slovenská pošta, a.s. (SP), ktorá ako jediný subjekt na poštovom trhu v SR požiadala o vydanie licencie na poskytovanie UPS. Poštovú licenciu na prevádzkovanie UPS vydal Poštový regulačný úrad, v Žiline 27. decembra 2002 pod číslom 1223/020/2002 pričom jej úplné znenie bolo vydané 28. apríla 2004 s číslom 589/001/2004. V poštovej licencii Poštový regulačný úrad vymedzil UPS vo vnútroštátnom a medzinárodnom poštovom styku a poštový platobný styk. Ako kompenzácia za poskytovanie UPS na poštovom trhu v SR by mala slúžit' možnost' poskytovat' vyhradené služby ${ }^{2}$ ) podl'a ustanovení Zákona o poštových službách č. 507/2001 Z.z. v znení neskorších predpisov, pričom za vyhradené služby sa považujú služby vyhradené pre poskytovatel'a UPS. Obsahom poštovej výhrady je vyberanie a distribúcia korešpondencie a RAZ s hmotnost'ou najviac $50 \mathrm{~g}$ a korešpondencie určenej do vlastných rúk účastníkom súdnych konaní a konaní pred správnymi orgánmi (do 31.12.2006). [6]

Uplatňovanie poštovej výhrady predstavuje pre poskytovatel'a UPS nepriame kompenzácie zo strany štátu za poskytovanie univerzálnej služby. Preto toto ustanovenie tvorcovia Zákona o poštových službách museli dat' do súladu s európskou legislatívou, ktorá už v tom období začala riešit' problematiku liberalizácie poštového trhu. Z tohto dôvodu bolo nevyhnutné presne zadefinovat' produkty, ktoré spadajú do univerzálnej služby a zabezpečit'

\footnotetext{
* prof. Ing. Mária Rostášová, PhD., Žilinská univerzita v Žiline, Fakulta Prevádzky a ekonomiky dopravy a spojov, Katedra spojov, Univerzitná 1, 01026 Žilina, tel. č.: 041/513 3109, fax: 041/ 5655 615, e-mail: Maria.Rostasova@fpedas.utc.sk

${ }^{+}$Ing. Miroslav Bát'ka, Žilinská univerzita v Žiline, Fakulta Prevádzky a ekonomiky dopravy a spojov, Katedra spojov, Univerzitná 1, 01026 Žilina, tel. č.: 041/513 2025, fax: 041/ 5655 615, e-mail:

Miroslav.Batka@fpedas.utc.sk

$\left.{ }^{1}\right) \S 7$, ods. 2 a 3, Zákona o poštových službách č. 507/ 2001 Z.z. v znení neskorších predpisov.

$\left.{ }^{2}\right) \S 7$, Zákona o poštových službách č. 507/ 2001 Z.z. v znení neskorších predpisov.
} 
ich oddelené účtovníctvo, aby nedochádzalo ku krížovým subvenciám a neprehl'adnostiam v ekonomickom systéme dominantného operátora. Ak by nebola dodržaná táto podmienka oddeleného účtovania produktov, ktoré spadajú do UPS podl'a zákona, tak by v budúcnosti nemohli byt' poskytovatel'om UPS kompenzované straty za poskytovanie univerzálnej služby a tým by bol dominantný operátor oproti súkromným operátorom znevýhodnený.

Príprava na liberalizáciu poštového trhu pozostáva z niekol'kých etáp, pričom v prvej sú vytvorené podmienky pre liberalizáciu v legislatívnych normách. Táto podmienka bola zavŕšená prijatím Zákona o poštových službách č. 507/2001 Z.z. a jej novelizácie č. 15/2004 Z.z. Ďalšou nevyhnutnou podmienkou pre zabezpečenie transparentného fungovania liberalizovaného trhu je existencia regulátora $\mathrm{v}$ oblasti poštových služieb, ktorý by mal zabezpečit' prehl'adné a rovnaké podmienky na trhu pre poštové podniky a zabezpečit' prístup k základným poštovým službám všetkým obyvatel'om na celom území štátu. Už v etape prípravy liberalizácie Slovenská republika zabezpečila vytvorenie nezávislého regulačného úradu, ktorým je Poštový regulačný úrad.

Poslednou etapou, ktorá završuje proces liberalizácie, je zrušenie vyhradených služieb u dominantného poštového operátora. [4] Členské štáty EÚ pristúpili k postupnému znižovaniu poštovej výhrady, pričom bol tento proces na základe odporúčaní v smernici Európskeho parlamentu a rady 2002/39/ES rozdelený do niekol'kých etáp.

\section{Časový harmonogram znižovania poštovej výhrady pre krajiny EÚ:}

- do 2002 - do 350 gramov (alebo 5-násobok základnej tarify)

- od 2003 - do 100 gramov (alebo 3-násobok základnej tarify)

- od 2006 - do 50 gramov (alebo 2,5-násobok základnej tarify)

- od 2009 - úplné zrušenie poštovej výhrady.

Slovenská republika ako nový štát EÚ mala ovel’a menší časový priestor na implementáciu harmonogramu znižovania poštovej výhrady. Nakol'ko pôvodné členské štáty EÚ mali na túto prípravu až sedemročný náskok, Slovenská republika musela stihnút' harmonizovat' všetky svoje legislatívne normy s normami EÚ týkajúce sa pôšt do 1. mája 2004, t.j. do dátumu vstupu SR do EÚ. Pre pôvodné štáty EÚ (15 štátov) bol tento termín stanovený do 31. decembra 2002. Pri porovnávaní harmonogramu znižovania poštovej výhrady bola pôvodná 15 -stka štátov vo výhode, nakol'ko miestni poskytovatelia UPS mali ovel'a väčší časový priestor na prípravu liberalizácie trhu.

\section{Časový harmonogram znižovania poštovej výhrady v Slovenskej republike:}

- do 31. 12. 2003 do 1000 gramov

- od 1. 1. 2004 do 350 gramov (alebo 5-násobok základnej tarify)

- od 1. 5. 2004 do 100 gramov (alebo 3-násobok základnej tarify)

- od 1. 1. 2006 do 50 gramov (alebo 2,5-násobok základnej tarify)

- od 1. 1. 2007 úplné zrušenie poštovej výhrady. [1]

Slovenská republika ako jedna z niekol'kých štátov by mala teda mat' už dva roky pred oficiálnym termínom úplne zrušenú poštovú výhradu. Úplná liberalizácia poštového trhu by mala byt' zavŕšená termínom, ktorý stanovila Európska komisia, t.j. rok 2009. Slovensko vd'aka termínu zrušenia poštovej výhrady by malo patrit' medzi niekol'ko štátov EÚ, ktoré výrazne pokročili pri liberalizácii trhu.

Termín liberalizácie poštového trhu nie je pevne stanovený, takže je pravdepodobné, že môže dôjst' k časovému posunu úplnej liberalizácie. To, či bude poštový trh úplne liberalizovaný je podmienené vypracovaním štúdie, ktorú by mala urobit' Európska komisia. V tejto štúdii sa má pre každý členský štát zhodnotit’ dopad úplného dokončenia vytvorenia 
vnútorného trhu poštových služieb na univerzálnu poštovú službu v roku 2009. Európska komisia má do 31. decembra 2006 predložit' Európskemu parlamentu a Rade správu o výsledkoch štúdie, v ktorej sa potvrdí rok 2009 ako dátum úplného dokončenia vytvorenia vnútorného trhu poštových služieb alebo sa na základe záverov štúdie stanovia d’alšie kroky. V tejto súvislosti sa liberalizácii trhu poštových služieb venuje aj Biela kniha o službách všeobecného ekonomického záujmu (COM(2004)374 final). [4]

\section{Prístup do poštovej siete v liberalizovanom prostredí}

V súvislosti s liberalizáciou poštového trhu sa v súčasnosti venuje vel'ká pozornost' len oblasti znižovania hmotnostných a cenových limitov poštovej výhrady, resp. zrušeniu poštovej výhrady. Je pravda, že zrušenie poštovej výhrady zasiahne práve príjmovú oblast' poskytovatel'ov UPS, ale pri súčasnom poukazovaní na liberalizáciu sa do popredia menej dostávajú ostatné aspekty liberalizácie poštového trhu. Až úplnou implementáciou všetkých oblastí možno hovorit' o úplnej liberalizácii poštového trhu. Nemenej dôležitou oblast’ou, ktorá sa ma liberalizovat', je prístup do poštovej siete poskytovatel'a UPS. O tejto oblasti možno hovorit', že je spomedzi všetkých ostatných oblastí najcitlivejšia, nakol'ko tu treba vymedzit' nové právomoci regulačnému orgánu, ktorý bude regulovat' poplatky za vstup do siete a vymedzovat' jednotlivé pravidlá prepravy zásielok od výmenného bodu operátorov až $\mathrm{k}$ adresátovi zásielky. Vel'mi závažným problémom sa tu javí nastavenie transparentného spôsobu merania kvality, nakol'ko v premiestňovacom procese bude figurovat' namiesto jedného subjektu už niekol'ko subjektov, podiel'ajúcich sa na poskytovaní poštových služieb. Podobná situácia je v sektore telekomunikácií preto je potrebné sa vyvarovat' chýb, ktoré nastali pri liberalizácii telekomunikačných služieb. Možno tu hovorit’ aj o tzv. „poslednej míli“, t.j. o fáze dodania poštovej zásielky. Táto tretia etapa premiestňovacieho procesu, (t.j. dodanie) tvorí až 60 \% nákladov z celkových nákladov vynakladaných na doručovací proces zásielky a výrazne ovplyvňuje spokojnost' zákazníkov s kvalitou poskytovaných poštových služieb. [1]

\section{Liberalizácia v krajinách EÚ}

Pri súčasnom pohl'ade na európsky poštový trh krajín EÚ možno konštatovat', že stupeň liberalizácie v jednotlivých krajinách EÚ je na rôznych úrovniach, čo závisí od národných špecifík a od vyspelosti technologických systémov v jednotlivých štátoch. Úplne liberalizovaný poštový trh má len vel'mi málo štátov. Medzi ne patrí Švédsko, kde sa liberalizoval poštový trh od roku 1993, Fínsko od roku 1994, Estónsko, kde bol trh liberalizovaný od roku 2002 a od 1.1. 2006 Vel'ká Británia. V ostatných štátoch bol proces liberalizácie postupne započatý, ale nie ešte zavŕšený. Slovenská republika a ostatné štáty EÚ pripravujúce sa na liberalizáciu majú rozdielne pohl'ady na liberalizačný proces, čo závisí od konkrétnych podmienok na danom území štátu. Túto skutočnost' potvrdil aj príklad Pol'ska a Malty, kde bola udelená výnimka na výšku výhrady v priebehu rokov 2004 a 2005 na úrovni 350 gramov, pričom smernica 2002/39/ES povol'ovala úroveň $100 \mathrm{~g}$. [3]

Vyhradené môžu byt', okrem korešpondencie, v súlade $\mathrm{s}$ ustanoveniami smernice 2002/39/EC, aj reklamné adresované zásielky a vystupujúce cezhraničné zásielky a to $\mathrm{v}$ rovnakých hmotnostných a cenových limitoch ako korešpondencia. Pokial' ide o reklamné adresované zásielky, v súčasnosti je táto oblast' liberalizovaná v nasledujúcich členských krajinách EÚ: Rakúsko, Dánsko, Vel'ká Británia, Španielsko, Taliansko, Lotyšsko, Holandsko, Česká republika ako aj v kandidátskych krajinách Rumunsko a Bulharsko.

Vystupujúce cezhraničné zásielky sú liberalizované v Rakúsku, Belgicku, Nemecku, Dánsku, Francúzsku, Vel'kej Británii, Írsku, Litve, Holandsku, Slovinsku. Z nečlenských krajín EÚ sú zásielky tohto druhu liberalizované aj v Nórsku a Rumunsku. Česká republika 
rovnako v novele zákona o poštových službách v roku 2004 zrušila poštovú výhradu na vystupujúce cezhraničné zásielky. [3]

Najväčšími poskytovatel'mi poštových služieb v rámci EÚ je Vel'ká Británia, Holandsko, Nemecko, ktorých podiel predstavuje $48 \%$ z celkového trhu poštových služieb EÚ.

Berúc do úvahy skutočnost', že štyri krajiny majú trh úplne liberalizovaný (1/2006), d'alšie tri krajiny plánujú zrušit' poštovú výhradu do konca roka 2007 a Španielsko má minimálnu výhradu, Európska komisia predpokladá, že približne $60 \%$ listovej pošty EÚ bude do konca roka 2007 otvorených hospodárskej sút'aži. Úplná liberalizácia trhu poštových služieb v SR, vzhl'adom na zanedbatel'ný podiel SR na celkovom listovom trhu EÚ (len cca $0,32 \%$ ), na jednej strane nezabezpečí, aby sa EÚ stala najkonkurencieschopnejšou ekonomikou sveta, na druhej strane však môže vážne narušit' stabilitu poskytovania univerzálnej poštovej služby v Slovenskej republike. [3]

Prehl'ad jednotlivých podielov poskytovatel'ov UPS na celkovom objeme EÚ vo vnútroštátnom poštovom trhu za rok 2002 je na nasledujúcom obrázku:

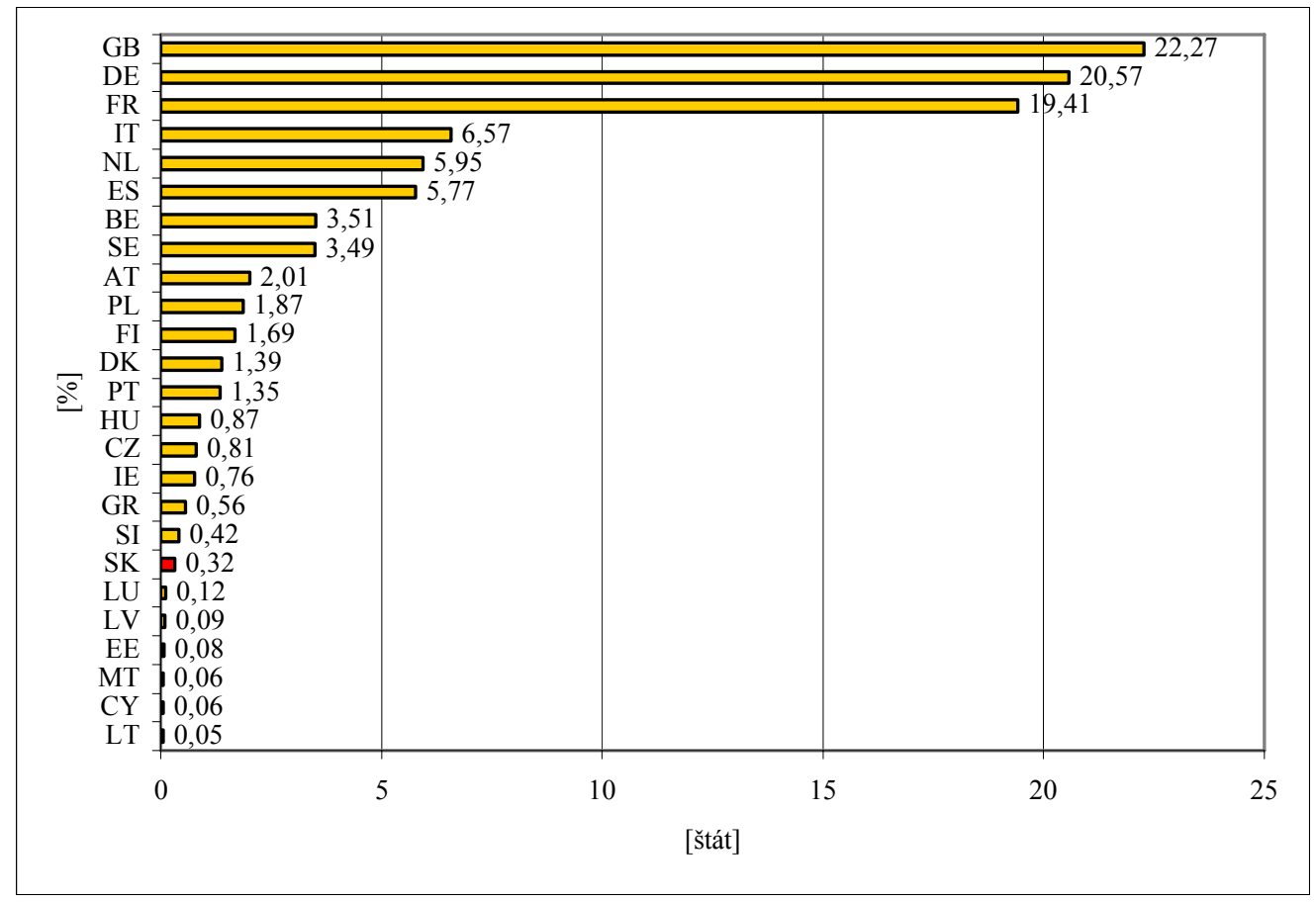

Obr. č. 1 Podiel poskytovatel'ov UPS na celkovom objeme EÚ - vnútroštátny poštový styk (2002) [2]

\section{4. Štáty s úplne liberalizovaným trhom v EÚ}

Pri podrobnejšej analýze už liberalizovaných trhov v štyroch krajinách EÚ zistíme, že v žiadnom štáte zatial' neexistuje spoločnost' na trhu, ktorá by v danom štáte mala väčší podiel na trhu a následne dokázala konkurovat' pôvodným poskytovatel'om UPS. O výraznom náraste trhových podielov súkromných poskytovatel'ov poštových služieb možno v budúcnosti uvažovat' len v hypotetickej rovine, nakol'ko je jasne deklarovaný vol'ný vstup na trh, ale následne je trh zo strany štátu chránený rôznymi reštrikčnými opatreniami.

Švédsko - poštový trh v oblasti UPS sa tu vyvíjal na komerčnom základe. Formálnu zodpovednost' za poskytovanie UPS má štát, pričom vláda uzavrela zmluvu o poskytovaní UPS so Švédskou poštou. Kompenzácie za poskytovanie UPS nevykrývajú celkové straty z prevádzky UPS. Podiel Švédskej pošty na trhu je približne $93 \%$. 
Fínsko - o podnikanie na poštovom trhu prejavili záujem viacerí poskytovatelia, pričom zatial' žiadny poskytovatel' doteraz neuspel. Hlavnou príčinou, ktorá bránila vstupu konkurencie na fínsky trh, sú požiadavky na normy kvality a finančné požiadavky, ktoré musí splnit' každý nový operátor. Podl'a fínskych zákonov musí každý operátor, teda nielen na poskytovatel' univerzálnej služby vyberat' a doručovat' zásielky každý deň a doručovat' $95 \%$ vnútroštátnych zásielok nasledujúci deň po dni podania. Dalšie obmedzenie predstavuje systém poplatkov, podl'a ktorého musí každý operátor, ktorý poskytuje poštové služby len v určitej časti krajiny, (teda nie na celom území), ktorého hustota je viac ako 250 obyvatel'ov na $\mathrm{km}^{2}$, zaplatit' poplatok, ktorý sa rovná $20 \%$ jeho obratu. Na druhej strane, ak je priemerná hustota územia, na ktorom poskytuje služby, menej ako 250 obyvatel’ov na $\mathrm{km}^{2}$, neplatí operátor žiadne poplatky.

Estónsko - trh je plne liberalizovaný, avšak tu existuje licenčný systém. Licencia je potrebná v troch prípadoch: na poskytovanie univerzálnej poštovej služby, na vnútroštátnu prepravu balíkov $\mathrm{s}$ hmotnost'ou nad $10 \mathrm{~kg}$ a na vykonávanie peňažných prevodov a platieb dôchodkov a ostatných sociálnych dávok. Licencia na poskytovanie univerzálnej poštovej služby sa poskytuje len na celý balík univerzálnej služby. Podmienky požadované na základe licencie je však schopný splnit' len súčasný držitel' licencie, ktorým je Estónska pošta.

Vel'ká Británia - úplné otvorenie poštového trhu nastalo 1. 1. 2006. Proces liberalizácie sa začal už v roku 1981. [3]

\section{Stupeň liberalizácie v krajinách EÚ}

Pri posudzovaní stupňa liberalizácie v jednotlivých krajinách EÚ je dôležitým ukazovatel'om, tzv. liberalizačný index, ktorý predstavuje dosiahnutý stupeň liberalizačného procesu $\mathrm{v}$ jednotlivých krajinách. Trh s nulovým indexom je doteraz plne regulovaný a nedošlo na ňom k žiadnej liberalizácii. Trh s indexom 100 znamená vol'ný trh s vel'kým počtom poštových operátorov s podobnými podielmi na trhu a bez akýchkol'vek právnych obmedzení, ktoré by sa týkali konkurencie.

Liberalizačný index predstavuje výsledný konkurenčný a rastový potenciál a má dve zložky. Prvá zložka je finančná (kvantitatívna), ktorú je možné jednoznačne finančne vyjadrit' (podiel na trhu $\mathrm{s}$ vol’ným prístupom $\mathrm{v} \%$, podiel na trhu, ku ktorému treba licenciu $\mathrm{v} \%$, skutočné využitie vol'ného prístupu na trh alebo licenčného trhu, podiel najväčšieho účastníka na trhu a podiel piatich najväčších účastníkov na trhu). Druhá zložka liberalizačného indexu je kvalitatívna zložka, ktorá zahŕňa právne podmienky, stupeň liberalizácie, súčasné konkurenčné podmienky a prekážky vstupu konkurenčných firiem na poštový trh, ktorý dovtedy ovládal monopolný poštový operátor.

Celkový index sa stanoví výpočtom ako priemer finančnej a kvalitatívnej zložky. Porovnaním stupňa a kvality liberalizácie poštových trhov, je možné poukázat' na stav v jednotlivých krajinách (rok 2001). Nízky stupeň má Grécko (37), Švajčiarsko (38), Belgicko (43), Taliansko (45), Írsko (46), USA (47), Francúzsko (48), Portugalsko (50), Nórsko (50), stredný stupeň je charakteristický pre Vel'kú Britániu (51), Rakúsko (51), Dánsko (56) a Španielsko (61). Vysoký stupeň sa prejavuje u krajín, ktoré možno považovat' z hl'adiska technologickej pripravenosti na liberalizáciu poštových služieb na najlepšej úrovni, resp. u krajín, v ktorých už liberalizácia prebehla (Nemecko (70), Holandsko (72), Fínsko (77) a Švédsko (79)). [3,5]

\section{Záver}

Proces liberalizácie v siet’ových odvetviach je v značnej miere komplikovaný, nakol'ko pre toto odvetvie je prirodzené, že na trhu existovali niekol'ko desat'ročí monopolné organizácie. Snahou Európskej únie je stat' sa čo najskôr najkonkurencieschopnejšou ekonomikou sveta, čo chce EÚ dosiahnut' aj liberalizovaním siet'ových odvetví - energetiky, 
vodárenstva a v poslednom období aj poštového sektora. Ako najväčší problém sa tu javí budovanie infraštruktúry, ktorá by mala zabezpečit' čo najväčšie pokrytie obyvatel'stva. Aby sa vstupné náklady nových operátorov čo najviac minimalizovali, mal by im byt' umožnený prístup do siete dominantného poštového operátora. A práve tu sa nachádza najväčší problém, ktorý bráni vo väčšom náraste súkromných operátorov. V prípade, ak príde nový operátor na trh, bude musiet' čelit' vel'kému ekonomickému tlaku zo strany dominantného poštového podniku. Jediná cesta k udržaniu sa dominantného operátora na poštovom trhu je priniest' ovel'a vyššiu pridanú hodnotu pre zákazníkov a nadviazat' spoluprácu s čo najväčším počtom malých poštových operátorov, resp. doručovacích spoločností. Jedno je však isté, že pokial' národný operátor nebude mat' podporu zo strany regulátora a štátnych inštitúcií udržanie výšky jeho podielu na trhu bude ohrozené.

\section{Použitá literatúra}

[1] BÁŤKA, M.: Nové formy podnikania na poštovom trhu. Diplomová práca 5/2004 KS, vedúci diplomovej práce: prof. Ing. Mária Rostášová, ŽU v Žiline, Katedra spojov.

[2] CAMPBELL, J. I., DIEKE, A. K., NIEDERPRUM, A.: Main Devopments in the European Postal Sector - Final Report, Bad Honnef, 2004, 233 s.

[3] Analýza možností a návrh urýchlenia liberalizácie trhu s poštovými službami od 1. januára 2006 (http://www.telecom.gov.sk/index/go.php?id=1468) [17.11.2005].

[4] Koncepcia rozvoja univerzálnej poštovej služby,(interný materiál Ministerstva dopravy pôšt a telekomunikácií).

[5] Správa Bundesverbandes Deutscher Postdienstleister e.V. (BvDP, Germany) Outline of the 2001 Edition [5.1.2006].

[6] Zákon o poštových službách č. 507/ 2001 Z.z. v znení neskorších predpisov.

\section{Grantová podpora}

Tento príspevok bol pripravený v rámci riešenia úlohy VEGA 1/2548/05 s názvom Kvalita služieb vnímaná zákazníkom, ktorej súčast’ou je aj tento príspevok. 